\title{
POLITIK PENDIDIKAN ISLAM PADA MASA KEJAYAAN DINASTI ABBASIYAH: POLITIK KETENAGAAN
}

\author{
Nurul Kawakib ${ }^{1}$
}

\begin{abstract}
Education as a social system, cannot be separated from the other system outside itself, is politic system. Both of them are two important elements in the social politic system of nation. The condition of social politic in the Abbasid era related with politic of manpower. Politic of manpower is education politic tends to be teacher oriented, not institution oriented. It's mean that the quality of education depends on the quality of teacher, not to institution. It can be evidenced by the condition in which students are free to choose the lesson as they want, they are not only study at mosque, but also at library, private house, and bookstore. They also choose a scholarly study or reference by teacher/scholar who teach them, not the institution.
\end{abstract}

Keywords: Politic of Islamic Education, Abbasid, Manpower

\section{A. Pendahuluan}

Pendidikan sebagai sebuah sistem sosial, tidak bisa lepas dari sistem lain diluar dirinya, yaitu sistem politik. Keduanya adalah dua elemen penting dalam sistem social politik di sebuah negara. Menurut Sirozi, pendidikan dan politik keduanya sama-sama saling menunjang dan saling mengisi. Lebih jauh disebutkan, bahwa lembaga-lembaga dan proses pendidikan mempunyai kontribusi yang penting dalam ikut membentuk perilaku politik masyarakat di negara tersebut. Begitu pula sebaliknya, lembaga-lembaga dan proses politik di suatu negara itulah membawa dampak besar pada karakteristik pendidikannya. (Sirozi, 2007: 1) Selanjutnya, menurut Sirozi, di negara-negara barat, kajian tentang hubungan antara pendidikan dan politik dimulai oleh Plato dalam bukunya Republic. Walaupun utamanya membahas berbagai persoalan kenegaraan, buku tersebut juga membahas hubungan antara ideology dan institusi negara dengan tujuan dan metode

1 Dosen Fakultas Ilmu Tarbiyah Dan Keguruan Universitas Islam Negeri Maulana Malik Ibrahim Malang J1. Gajayana No. 50 Malang 65144 
pendidikan. Plato mendemonstrasikan dalam buku tersebut bahwa dalam budaya Helenik, sekolah adalah salah satu aspek kehidupan yang terkait dengan lembaga-lembaga politik. Menurut Nurcholis Madjid, istilah "Hellenisme" pertama kali diperkenalkan oleh ahli sejarah dari Jerman, J.G. Droysen. Droysen menggunakan istilah "Hellenisme" sebagai sebutan untuk masa yang dianggapnya sebagai periode peralihan antara Yunani kuno dan dunia Kristen. (Nurcholis, 1995: 233) Ia menjelaskan bahwa setiap budaya mempertahankan control atas pendidikan di tangan kelompok-kelompok elit yang secara terus menerus menguasai kekuasaan politik, ekonomi, agama dan pendidikan. Plato menggambarkan adanya hubungan dinamis antara aktivitas kependidikan dan aktivitas politik. Keduanya seakan dua sisi dari satu koin, tidak mungkin terpisahkan. Walaupun sangat umum dan singkat, analisis Plato tersebut telah meletakkan fundamental bagai kajian hubungan politik dan pendidikan di kalangan generasi ilmuwan generasi berikutnya. (Sirozi, 2007: 7)

Terkait dengan sistem pendidikan suatu hal yang mendasar adalah terkait dengan pelaku pendidikan itu sendiri dalam hal ini guru, murid, orang tua murid, dan begitu pula kaitannya dengan pihak-pihak yang terkait struktur social masyarakat dan pihak-pihak yang berkepentingan lainnya. Dalam pandangan Abernethy dan Coombe -sebagaimana dikutip Sirozieducation and politics are inextricably linked (pendidikan dan politik terkait tanpa bisa dipisahkan). Hubungan itu dapat dilihat dari tiga aspek, yaitu pembentukan sikap kelompok (group attitudes), masalah pengganguran (unemployment), dan peranan politik kaum cendekia (the political role of the intelegentsia). (Sirozi, 2007: 7) Juga disebutkan pula " the form of political system will affect the content and control of the educational process. The expectation of family in socializing the child to be a productive member of society will affect the type of educational content". (Ballantine, 1993: 27-28) Dengan perspektif-perspektif tersebut, penulis selanjutnya dalam tulisan ini akan berusaha memfokuskan pada kajian politik pendidikan pada masa Abbasiyah, penulis berupaya mendapatkan data khususnya yang terkait dengan ketenagaan. 


\section{B. Sekilas Dinasti Abbasiyah}

Menurut Philip K Hitti, babak ketiga dalam drama besar politik Islam dimulai dengan peran penting yang dimainkan oleh khalifah Abu al-Abbas (750-754). Irak menjadi panggung drama besar itu. Dalam khutbah penobatannya yang disampaikan setahun sebelumnya di masjid Kufah, khalifah Abbasiyah pertama itu menyebut dirinya al-saffah, yang artinya penumpah darah, yang kemudian menjadi julukannya. Julukan itu menunjukan pertanda buruk, karena dinasti yang baru muncul ini mengisyaratkan bahwa mereka lebih mengutamakan kekuatan dalam menjalankan kebijakannya. Untuk pertama kalinya dalam sejarah Islam, di sisi singgasana khalifah tergelar karpet yang digunakan sebagai tempat ekskusi.

Ketika berhasil merebut kekuasaan, orang Abbasiyah mengklaim dirinya sebagai pengusung konsep sejati kekhalifahan, yaitu gagasan negara teokrasi, yang menggantikan pemerintahan sekuler Dinasti Umayah. Sebagai ciri khas keagamaan dalam istana kerajaannya, dalam berbagai kesempatan serimonial, seperti ketika dinobatkan sebagai khalifah dan pada saat sholat Jum'at, khalifah mengenakan jubah (burdah) yang pernah dipakai oleh saudara sepupunya, Nabi Muhammad SAW. (Philip, 358)

Dinasti Abbasiyah, seperti halnya dinasti lainya dalam sejarah Islam, mencapai masa kejayaan politik dan intelektual mereka segera setelah didirikan. Kekhalifahan Baghdad yang didirikan oleh al-Shaffah dan alMansur mencapai masa keemasannya antara masa khalifah ketiga, al-Mahdi dan khalifah kesembilan, al-Wastiq dan lebih khusus lagi pada masa Harun al Rasyid dan anaknya, al Ma'mun. Karena dua khalifah hebat itulah Dinasti Abbasiyah memiliki kesan baik dalam ingatan public, dan menjadi dinasti yang paling terkenal dalam sejarah Islam. Diktum yang ditulis dari seorang penulis al-Tsa'alabi (w. 1038) bahwa dari para khalifah "sang pembuka" adalah al-Manshur, "sang penengah" adalah al-Ma'mun dan "sang penutup" adalah al Mu'tadhid (892-902). Setelah al-Wastiq pemerintahan mulai menurun hingga pada ahirnya pada masa khalifah al Mu'tasim, khalifah ke-38, dinasti tersebut mengalami kehancuran ditangan orang Mongol pada tahun 1258. (Philip, 369) 


\section{Status Sosial Guru Pada Periode Abbasiyah}

Merujuk pada literature penulis menemukan beberapa istilah terkait dengan pembahasan istilah Guru. Hal yang mendasar terkait dengan perbedaan istilah tersebut adalah, bahwa perbedaan terminology, ternyata juga mengisyaratkan status social guru yang dimaksud, istilah tersebut antara lain, mu'alim, mu'adib, faqih, shaikh, dan mudaris. Hal ini sebagaimana dikemukakan Goerge Makdisi:

"... the terms mudaris and sheikh were used to designate the holders of the topmost teaching level. Mudaris, when used without a complement, designated the professor of law, whereas shaikh was generally used for professors of all other fields: koranic science, hadits, grammar, including the literary of arts;Sufism; and all fields of foreign sciences; the complement designated the field concerned". (terms mudaris dan syekh digunakan untuk level yang paling tinggi dalam pengajaran. Mudaris digunakan tanpa keterangan tambahan (pelengkap), maka merujukpada guru besar hukum, sedangkan sheikh merujuk pada professor bidang-bidang yang lain, seperti ilmu al-Qur'an, hadits, tata bahasa, termasuk bidang kajian sastra, sufi dan kata pelengkap merujuk pada bidang yang dimaksudkan). (Goerge Makdisi, 153)

Sementara itu guru di sekolah dasar disebut mu'alim (Muhaimin, 2005) kadang-kadang disebut faqih, yang secara khusus mengajarkan teologi, biasanya guru SD mendapatkan status sosial yang lebih rendah. Ada juga sebuah ungkapan populer yang menunjukan rendahnya status mereka; " seek no advice from teachers, shepherds or those who sit much among women" (jangan meminta nasihat dari guru, pembimbing dan orang yang terlalu banyak bergaul dengan wanita"). Seorang hakim pada masa kekhalifahan al-Ma'mun bahkan bertindak lebih jauh lagi dengan menolak kesaksian para guru dan menganggapnya sebagai bukti yang lemah di pengadilan (elementary teachers-in same cases, were not considered satisfactory witnesses in court). Ada juga anekdot yang tersebar luas yang mengolok-olok guru-guru SD, misalnya, "kamu lebih bodoh ketimbang guru SD (stupider than a schools master)". (Philip, 2002) Suatu hal yang menggelikan, adalah sebuah kisah yang mengilustrasikan tentang status social guru SD, bahwa guru SD bisa diperdayai oleh murid-muridnya. Dikisahkan, seorang murid SD berpura-pura sakit, maka teman-temanya 
juga bersandiwara mengekspresikan kesedihan atas kondisi sakit temannya, kemudian satu demi satu teman-temannya menganjurkan agar istirahat, ahirnya guru bodoh terperangkap masuk jebakan murid-muridnya, dan Guru SD akhirnya meninggalkan kelas dan pergi tidur, dan juga memberikan izin pada murid-muridnya untuk tidak masuk sekolah. (Ahmad Shalaby, 121) Dari fenomena diatas, kita bisa menyimpulkan rendahnya pemahaman tentang pentingnya pendidikan dasar terkait dengan tenaga guru pada masa itu. Padahal dalam konteks ilmu pendidikan, pendidikan dasar mempunyai peran yang sangat strategis, karena dialah peletak dasar bagi perkembangan anak didiknya dalam jenjang level pendidikan berikutnya.

Adapun istilah mu'adib berarti guru adab, kajian humaniora, akhlak dan budi pekerti. Istilah nahwi merujuk pada kepakaran tata bahasa (nahwu) dan materi-materi pelajaran sastra lainya. Istilah mu'aadib, mukatib, mu'alim, merupakan bentuk isim fail (subjek pelaku) yang berarti menulis melalui pendiktean, sebuah metode yang tidak hanya dipakai untuk proses pengumpulan hadist, tetapi juga digunakan untuk mencatat bahan-bahan pelajaran dalam kajian humaniora. Ada satu istilah lain yang secara khusus diterapkan pada para pelajar yang mempelajari kajian humaniora secara privat atau magang di sekolah-sekolah, kantor administrasi pemerintah, di lembaga pelatihan kerja, dan dalam program praktik kerja, yaitu muta'adib. Istilah ini sepadan dengan istilah mutafaqih bagi pelajar ilmu hukum (fikih). (Goerge, 372)

Fenomena lain terkait dengan status social guru, adalah terkait dengan pemberian sertifikat dan perlakuan terhadap guru yang mengajar pada jenjang lebih tinggi. Kalau pada pendidikan dasar, telah dibahas keadaan gurunya yang cenderung diklasifikan mempunyai status yang rendah. Namun kondisi sebaliknya, ada pada status social guru-guru di sekolah yang lebih tinggi, mereka mendapatkan kedudukan dan penghormatan yang lebih baik. Mereka berkumpul dalam suatu organisasi tertentu dan seorang guru akan memberikan certificates (ijazah) kepada muridnya yang sukses menempuh pendidikan dibawah bimbingannya. Tradisi memberikan sertifikat ini dimulai oleh tradisi ahli hadist (muhadits) dimana murid yang belajar, dan menunjukan kemampuannya menguasai materi yang diajarkan berdasarkan kitab yang dikaji, maka guru akan memberikan sertifikat yang ditulis di halam paling depan yang tidak tercetak ( fly-leaf). Adalah 
Syekh Agha Burzuk al Najaf, seorang ulama' di Nadjaf menuturkan bahwa syahadah yang paling tua dikeluarkan pada tahun $304(\mathrm{H})$, diberikan oleh Muhammad ibn Abdullah ibn Ja'far al Himjari, kepada Abu Amir Said Ibn Umar. (Syalabi, 259)

Terkait dengan pendidikan untuk orang dewasa, tidak hanya dikembangkan dengan cara-cara sistematis, atau dilembaga formal, tetapi juga dilakukan di masjid-masjid yang terdapat di kota muslim. Setiap masjid selain sebagai pusat aktivitas keagamaan- juga berfungsi sebagai pusat-pusat pendidikan penting. Selain sebagai pusat pendidikan masjid juga berfungsi sebagai tempat menyimpan buku. Fenomena semacam inilah yang dicatat oleh Maqdisi ketika mengunjungi kota Susa. Ahli Geografi yang senang mengembara ini (hidup ada abad ke-10) menemukan berbagai halaqah, atau lingkaran pendidikan di Palestina, Suriah, Mesir dan Paris.

Mengenai batas waktu yang harus ditempuh oleh pelajar agar menyelesaikan studinya tida ada keseragaman. Hal ini tergantung pada minat murid. Alasan mengapa batas waktu yang harus ditempuh oleh si pelajar tidak seragam adalah :

1. Karena guru-guru, bahkan lembaga-lembaga pendidikan tidak pernah menawarkan pelajaran khusus yang harus diselesaikan pada waktu tertentu.

2. Sudah menjadi ciri sistem pendidikan Islam pada masa klasik, bahwa pelajar diberi kebebasan untuk belajar kepada siapa saja dan kapan saja ia menyelesaikan pelajarannya.

Oleh karena itu, murid-murid bebas memilih guru yang mereka sukai dan mereka anggap paling baik. Mereka bebas pindah dari satu guru kepada guru lain jika ia merasa bahwa guru tersebut yang lebih bagus.

\section{Pendidikan Bagi Wanita}

Sejak masa Abbasiyah telah ditemui wanita-wanita yang belajar, Fayyas Mahmud,- sebagaiman dikutip Hanun Asrohah-, menjelaskan anak-anak perempuan mempunyai kesempatan untuk belajar di maktab. (Fayyaz Mahmud, 1960: 133) Akan tetapi tidak banyak data yang menerangkan bahwa wanita-wanita pun ikut belajar di lembaga pendidikan tinggi. Syalabi tidak mengingkari adannya pengajaran untuk wanita dan anak-anak 
perempuan. Namun, ia menolak adanya pengajaran anak-anak perempuan secara terbuka dan terlibat interaksi langsung dengan murid-murid laki-laki. Lebih lanjut Syalabi menjelaskan memang ditemukan teks yang menjelaskan tentang anak perempuan yang mengikuti pelajaran pada sebuah sekolah tingkat dasar. Kedua perempuan tersebut adalah hamba sahaya, bukan orang merdeka. Oleh sebab itu, Syalabi menolak bahwa pengajaran untuk budak dapat dinilai sebagai "pendidikan" karena pengajaran untuk budakbudak hanyalah untuk menaikan harga mereka dengan cara mengajar mereka membaca menulis. (Ahmad Syalaby, 335-338)

Dengan demikian catatan tersebut tidak bisa dipakai bukti sebagi politik kebijakan terkait dengan pendidikan bagi wanita. Boleh jadi pengajaran untuk anak-anak perempuan tidak dilaksanakan secara terbuka dengan siswa laki-laki, tetapi mereka mendatangkan guru-guru privat. Karena itu bisa dikatakan kesadaran untuk pendidikan bagi wanita pada masa Abbasiyah, hanya pada level dasar, belum sampai pada level yang lebih tinggi.

\section{E. Perpustakaan dan Toko Buku}

Sebagaimana disebutkan selain sebagai tempat ibadah dan pusat pendidikan, masjid juga sebagai tempat penyimpanan buku. Buku-buku itu didapatkan dari hadiah-hadiah yang diberikan kepada pengurus masjid atau hasil pencarian dari berbagai sumber. Karenanya, masjid pada saat itu memiliki khazanah buku-buku keagamaan yang sangat kaya. Salah seorang donatur buku-buku itu adalah sejarawan terkenal yaitu al-Khatiib al-Baghdadi (1002-1071) yang menyerahkan buku-bukunya sebagai wakaf untuk ummat Islam. Perpustakaan-perpustakaan lainya juga dibangun oleh bangsawan atau orang kaya sebagai lembaga-lembaga kajian yang terbuka untuk umum, menyimpan koleksi buku logika, filsafat, astronomi, dan bidang ilmu lainnya. Para pelajar dan para ahli bisa mengakses bukubuku yang mereka inginkan dengan mudah, bahkan ke perpustakaan pribadi. Pada pertengahan abad ke-10 kota Mosul memiliki perpustakaan yang dibangun oleh salah seorang penduduknya. Di dalam perpustakaan itu, para pelajar yang mengunjunginya bisa mendapatkan kertas dan alat tulis lain secara gratis. Secara politik perhatian pemerintah terhadap perpustakaan ditunjukan pada masa penguasa Buwaihi, Adud al Dawlah 
(977-982) yang berhasil membangun perpustakaan di Syiraz. Pada saat itu buku-buku sudah tertata dengan rapi di atas lemari-lemari, didaftar dalam catalog, dan diatur dengan baik oleh staff administrator yang berjaga secara bergiliran. Pada abad yang sama, kota Bashrah memiliki sebuah perpustakaan yang didalamnya para ilmuwan bekerja dan mendapatkan upah atau gaji dari pendiri perpustakaan. Sedangkan di Kota Rayy terdapat sebuah tempat yang disebut dengan " Rumah Buku”, disebutkan bahwa tempat itu menyimpan ribuan manuskrip yang diangkut oleh lebih dari empat ratus ekor unta. Seluruh naskah-naskah itu kemudian didaftar dalam sepuluh jilid catalog.

Selain perpustakaan gambaran tentang ketenagaan, juga tercermin dengan keberadaan toko-toko buku. Toko-toko buku pada masa itu berfungsi juga sebagai "agen pendidikan", fenomena ini mulai muncul sejak awal kekhalifahan Abbasiyah. Disebut sebagai agen pendidikan karena para pemilik dan penjual buku sekaligus berprofesi sebagai penulis, penyalin, dan ahli sastra yang menjadikan toko buku itu tidak hanya sebagai tempat jualan, tetapi juga sebagai pusat kegiatan ilmiah. Mereka mendapat kedudukan terhormat di masyarakat. Yaqut seorang penulis kamus geografi, memulai karirnya sebagai pegawai di sebuah toko buku. Kemudian Al-Nadim (w 995) yang juga disebut al-Waraq (lembar kertas), menjalani karirnya sebagai pustakawan dan penjual buku yang kemudian menulis sebuah karya besar berupa catalog berjudul al-Fihrist yang diakui oleh kalangan akademisi dan ilmuwan sebagai karya yang sangat baik. (Philip: 521)

\section{F. Jabatan dan Penghasilan}

Besaran gaji untuk para guru besar di lembaga-lembaga pendidikan tinggi hukum pada umumnya sama di seluruh kekhalifahan, yaitu sepuluh dinar setiap bulan. Alasannya sudah pasti karena sumber pemasukan bagi lembaga pendidikan tinggi tersebut berasal dari sumbangan, sewa gedung, hasi panen dari tanah pertanian dan sebagainya. Pemasukan dari sumber-sumber semacam ini tidak berbeda jauh. Kelebihan yang didapatkan dari pemasukan pada tahun-tahun gemuk disisihkan untuk menomboki kekurangan di tahun-tahun kurus. Karena gaji untuk pengurus dan guru besar bisa tetap diberikan dengan lancar. Keadaan ini berlangsung di lembaga-lembaga pendidikan tinggi hukum. Keadaan berbeda pada 
dalam pembelajaran bidang-bidang pengetahuan lain seperti adab, yang keberlangsungannya tergantung pada kebijakan pemerintah atau pada pejabat tinggi. Di lembaga semacam ini, pembayaran gaji bagi para guru berfluktuasi secara mencolok. Kadang-kadang para sastrawan mendapatkan penghargaan yang sangat tinggi berupa hadiah yang sangat besar, dan bahkan kadang-kadang juga jumlahnya sedikit, bahkan tak jarang hanya mendapatkan ucapan terima kasih.

Meskipun demikian, pendapatan seorang guru besar fikih tidak mempresentasikan gaji yang sebenarnya, karena mungkin saja ia menduduki beberapa jabatan pada waktu yang sama. Misalnya, ada orang yang menduduki jabatan guru besar fikih di beberapa lembaga pendidikan tinggi, kemudian ia mengupah guru-besar pengganti dan memberinya sebagian dari gaji yang ia terima. Atau ada juga yang sekaligus menjabat sebagai qodi (hakim) yang mendapatkan gaji magistrat (pejabat di kantor pengadilan). Atau jika tempat mengajarnya berada di lingkungan penguasa, sangat mungkin ia juga menjadi tutor bagi anak-anak mereka, atau menjadi pendamping setia mereka, penggubah syair pujian, atau sekretaris yang menerima gaji untuk setiap posisi yang dipegangnya.

Ada perbedaan penting antara sistem pendidikan hukum di lembagalembaga pendidikan tinggi hukum, dan pendidikan adab di luar lembagalembaga pendidikan itu; lembaga yang pertama membebaskan siswanya dari biaya studi, memberikan beasiswa, pemondokan dan makanan gratis. Sedangkan institusi pendidikan $a d a b$, termasuk diluar lembaga-lembaga pendidikan yang disubsidi, seringkali menetapkan bayaran yang sangat mahal. Secara umum, pendidikan hukum di lembaga-lembaga pendidikan yang didanai diperuntukkan bagi para mahasiswa miskin, sedangkan pendidikan adab biasanya diperuntukkan bagi kalangan yang berduit. (George, 2000: 376)

Setiap tingkatan pegawai atau pakar menerima gaji bulanan yang berbeda-beda sesuai dengan jabatan dan periode kerja. Gaji bulanan para pegawai pemula di kantor-kantor pemerintahan (diwan) berkisar antara sepuluh sampai dua puluh dinar, sama dengan atau lebih besar dari gaji seorang guru besar hukum. Seorang ahli nahwu yang buta, Hisyam ibn Mu'awiyah (w 209H/824 M), salah satu murid al- Kisai, mendapatkan gaji bulanan sebesar sepuluh dinar sebagai guru untuk seorang anak 
pejabat pemerintah. Ibn al-'Arabi, anak tiri al-Muhafahdal al Dzabbi yang dibawah bimbingannya ia belajar syair Arab kuno, dan juga murid al-Kisai, mendapatkan gaji bulanan sebesar 1000 dirham, atau setara dengan 65 dinar.

\section{G. Kesimpulan}

Diantara kondisi sosial politik pendidikan pada masa abbasiyah terkait dengan politik ketenagaan adalah bahwa politik pendidikannya cenderung berorientasi teacher oriented, bukan institution oriented. Maksudnya adalah kualitas suatu pendidikan bergantung kepada kualitas guru, bukan pada lembaga. Hal ini dibuktikan dengan kondisi dimana pelajar bebas mengikuti suatu materi pelajaran yang mereka kehendaki, mereka tidak hanya belajar di masjid, tetapi juga di perpustakaan, rumah pribadi, bahkan toko-toko buku. Mereka juga memilih sebuah kajian keilmuan merujuk atau berdasarkan guru/ulama' yang mengajarkannya, bukan lembaganya. Oleh karena itu, mereka tidak harus belajar di lembaga keagamaan seperti masjid, tetapi mereka bisa belajar di berbagai perpustakaan, toko buku, rumah ulama, dan bahkan tempat terbuka. Sebagai dampaknya, maka ada budaya pelajar tidak puas hanya belajar kepada sedikit guru. Jika seorang pelajar tidak puas dengan pengetahuan yang dia peroleh dari gurunya, maka ia akan mencari guru yang lain, bahkan bila di kota tempat si murid tinggal tidak ada guru yang dia kehendaki, maka ia akan pindah ke kota lain (rihlah ilmiah) untuk belajar kepada guru-guru yang ia ingginkan sampai merasa cukup. Karena tidak ada batasan untuk mengikuti pelajaran suatu guru dan tidak terikat dengan tempat belajar, tidak jarang murid mempunyai guru yang sangat banyak dan variatif, sehingga sang penuntut ilmu memiliki jaringan guru dan social yang sangat luas.

Ada perbedaan terkait dengan penghargaan terhadap pengajar ilmu hukum dan ilmu adab dan humaniora. Adanya kecenderungan gaji yang tinggi bagi pakar hukum. Begitu pula factor kedekatan dengan penguasa juga menjadi salah satu pembeda dalam penerimaan gaji, guru yang mengajar dilingkup kekuasaan pada umumnya mendapat gaji yang lebih banyak. 


\section{Daftar Pustaka}

M. Sirozi, Politik Pendidikan: Dinamika hubungan antara kepentingan kekuasaan dan praktik penyelenggaraan pendidikan (Jakarta: Rajawali Press, 2007).

Nurcholis Madjid, Islam Doktrin dan Peradaban: sebuah telaah kritis tentang masalah keimanan, kemanusiaan, dan kemerdekaan (Jakarta: Paramadina, 1995).

Jeanne H. Ballantine, The Sociology of Education: A systematic analysis (New Jersey: Printice Hall, 1993).

Muhaimin, Pengembangan Kurikulum di Sekolah, Madrasah dan Perguruan Tinggi (Jakarta: Rajawali Press, 2005).

Philip K. Hitti, History of the Arabs, (New York: Palgrave Pacmillan, 2002).

Ahmad Shalaby, History of Muslim Education.

Fayyaz Mahmud, A Short History of Islam (London: Oxford University Press, 1960).

George Makdsi, The rise of humanism in Classical Islam and the Christian West (Edinburg: Edinburg University Press, 2000). 
